\title{
Best behandling i sykehjem
}

\author{
Pleie, omsorg, ro og verdighet samt symptomrettet og lindrende behandling bør i større grad vektlegges \\ i håndteringen av eldre og alvorlig syke mennesker. Ofte vil den beste helhetlige behandlingen kunne \\ administreres ved sykehjemmet heller enn i en spesialisert og travel sykehusavdeling.
}

En sykehjemsbeboer i 90-årsalderen blir innlagt i medisinsk avdeling med diagnosen hjertesvikt og pneumoni. Hun har vært tiltakende dårlig de siste ukene og forsøkt behandlet ved sykehjemmet uten ønsket effekt. Hvordan skal man best kunne ivareta henne videre? Vil sykehusinnleggelse være beste alternativ eller vil man kunne gi adekvat behandling i sykehjemmet?

Pasienten ble innlagt i sykehus da hun ikke hadde ønsket effekt av sykehjemsbehandlingen. Tilstanden var tolket som hjertesvikt i forverring og pneumoni. Hun var mentalt klar og fast beboer ved sykehjem. Nærmeste pårørende var barna, og både pasienten og pårørende syntes å ønske sykehusinnleggelse og full videre behandling. Det ble likevel fra mottakende lege besluttet at pasienten ikke var kandidat for respiratorbehandling eller hjerte-lunge-redning. Hun fikk vanndrivende medikament og antibiotika intravenøst. Det kliniske bildet kunne være forenlig med lungeemboli, men hun var ikke tilgjengelig for avklarende bildediagnostikk. Hun kom seg noe etter behandlingen og ytret raskt ønske om å få komme tilbake til sykehjemmet. Dette ble etterkommet, og hun ble etter få dagers innleggelse i sykehus utskrevet til sykehjemmet. Under innleggelsen ble hun oppfattet som urolig og mentalt uklar nattestid. På utskrivningstidspunktet ble det rapportert at hun var i beskjeden klinisk bedring.

\section{Sykehusinnleggelse?}

Slike pasienthistorier er vanlige i medisinske avdelinger. Flere vil kunne kjenne seg igjen både i rollen som legevaktlege, som den som i samarbeid med pleiepersonellet ved sykehjemmet beslutter at pasienten bør innlegges i sykehus og som sykehuslegen som făr ansvaret for den videre behandlingen. Beboere ved sykehjem har høy alder, ofte flere sykdommer, og andelen eldre i befolkningen øker stadig (1).

Riktig behandling av denne pasientgruppen kan være vanskelig og krever individuell vurdering. Akutte sykdomsepisoder er vanlig og kanskje særlig blant beboere ved sykehjem. Personalet står da overfor spørsmålet om sykehusinnleggelse. Dette omfatter både medisinske og etiske overveielser. Flere faktorer vil spille inn, deriblant geografi og transportvei til sykehus, tilgjengelige ressurser i sykehjemmet og pasientens og pårørendes ønske. Trolig er det stor variasjon i behandlingspraksis mellom de ulike sykehjemmene.

En oversiktsartikkel i Tidsskriftet belyser i hvilke situasjoner det er hensiktsmessig med innleggelse av sykehjemsbeboere

i sykehus (2):

- diagnostikk og avklaring

- behandling som bedrer overlevelse og funksjon

- lindrende behandling

I samme artikkel konkluderes det med at man kan forbedre praksis i sykehjemmene ved å øke legetjenestene, øke kunnskapen

\section{«Eldre og alvorlig syke mennesker har begren- set forventet levetid og det er viktig å formidle realistiske forventnin- ger til både pasient og pårørende ved akutt sykdom»}

om lindrende behandling og sammen med pasient og pårørende planlegge behandlingsnivå ved eventuell sykdom.

\section{Gjenværende forventet levetid?}

Eldre pasienter med flere alvorlige grunnsykdommer har generelt begrenset levetid. Amerikanske data gir oversikt over forventet gjenværende levetid avhengig av kjønn og alder (3). Ut ifra disse data ser man f.eks. at en 95 år gammel kvinnes mediane gjenværende levetid vil være 2,7 år. Men lider hun av alvorlig sykdom og dermed regnes å være mindre frisk enn gjennomsnittet for hennes alder, vil forventet gjenværende levetid være 1,1 år. Det er diskutert, og i flere tilfeller anbefalt, at man i en mer helhetlig medisinsk vurdering i større grad bør vektlegge forventet gjenværende levetid når man skal utrede og behandle eldre pasienter (3).

Det er ofte enklere å kontinuere utredning og behandling heller enn å avslutte eller begrense denne. En norsk undersøkelse om det å avslutte behandling viste at en tredel av norske leger av og til eller ofte har gitt behandling etter at de selv mente at denne burde vært avsluttet (4). Jeg mener dette ofte gjelder for eldre pasienter innlagt i spesialavdelinger i sykehus og at det kan bidra til overdiagnostikk og overbehandling.

\section{Pasienthistorien}

I den omtalte pasienthistorien vurderte sykehjemmet at pasienten ville ha nytte av sykehusinnleggelse for diagnostisk avklaring og behandling, de pårørende ønsket sykehusinnleggelse og det var kort transportvei mellom sykehjem og sykehus. Нøy alder og sykelighet begrenset imidlertid både diagnostikk og behandling, pasienten var urolig og utilpass i sykehuset og ytret ønske om utskrivning. Behandlingen som ble gitt var i stor grad symptomatisk og basert på relativt enkle og generelle kliniske undersøkelser og vurderinger.

Ble pasienten ivaretatt på en god måte? Var sykehusinnleggelse det beste behandlingsalternativet eller kunne hun mottatt behandling ved sykehjemmet?

Eldre og multimorbide pasienter skal selvsagt motta adekvat medisinsk utredning og behandling, og dette bør i hvert enkelt tilfelle vurderes medisinsk og etisk. Avgjørelsen om behov for sykehusinnleggelse må ligge i primærhelsetjenesten og helst hos en lege som kjenner pasienten. Bedre kommunikasjon mellom leger i sykehjem og sykehus vil kunne bidra til bedre ivaretakelse av denne gruppen. Eldre og alvorlig syke mennesker har begrenset forventet levetid og det er viktig å formidle realistiske forventninger til både pasient og pårørende ved akutt sykdom.

\section{Øyvind Bruserud \\ oeyvind.bruserud@helse-bergen.no}

Øyvind Bruserud (f. 1985) er lege i spesialisering og medlem av Klinisk etikkkomité ved Haraldsplass Diakonale Sykehus.

Forfatter har fylt ut ICJME-skjemaet og oppgir ingen interessekonflikter.

Litteratur

1. Statistisk sentralbyrå. Folkemengden 1. januar 2014. www.ssb.no/befolkning/statistikker/ folkemengde (17.11.2014).

2. Ranhoff AH, Linnsund JM. Når skal sykehjemspasienter innlegges i sykehus? Tidsskr Nor Lægeforen 2005: 125: 1844-7.

3. Walter LC, Covinsky KE. Cancer screening in elderly patients: a framework for individualized decision making. JAMA 2001; 285: 2750-6.

4. Førde R, Aasland OG, Falkum E. The ethics of euthanasia?attitudes and practice among Norwegian physicians. Soc Sci Med 1997; 45: 887-92.

Mottatt 28.8. 2014, godkjent 23.11. 2014. Redaktør: Erlend Hem.

Publisert først på nett. 